From the Anat. Labor. of Prof. H. SETO, Tohoku University, Sendai.

\title{
Innervation of Inferior Oesophagus and Pars Cardiaca Ventriculi in Dog.
}

\author{
犬食道下部及び胃噴門部の神経分布. \\ Gozaburo SUGAMATA 菅又䊖 三 郎.
}

[Recieved November 31, 1954.]

The histological study on the innervation of human and animal alimentary tracts has greatly progressed thanks to the invention of an ideal silver impregnation method by STÖHR in 1932 and its improvement by SETO of this laboratory. In particular, the sensory innervation has been well elucidated by many works in this laboratory. The discovery of sensory nerve fibres and their terminations in the digestive tracts from the oral cavity and the pharynx down to the oesophagus, the stomach and the duodenum fully deserves special mention.

To speak in details, SADA discovered comparatively numerous sensory terminations in the human oesophagus, SATO some in the stomach of human adults and embryos, OHI in the stomach and the duodenum of white mice, TOYOTA in the gastric wall of hedgehogs and SETO and UTSUSHI some remarkably well developed sensory terminations in the duodenum of human embryos. Thus, the supposed existence of afferent vegetative nerve fibres in these parts, generally accepted in the past, had to be emphatically discredited.

In succession to these studies, the author was given the opportunity to study the innervation of the canine oesophagus in its inferior part and the cardiac part of the stomach. The materials taken from three dogs were fixed in $10 \%$ neutral formol, cut into $40 \mu$ frozen sections and stained with SETO's silver impregnation. The ideal tissue preparations thus obtained, I subjected to minute microscopic examination which resulted in the interesting observations outlined hereunder.

\section{Individual Observations.}

The external nerves supplying the inferior oesophagus and the cardiac part of the stomach of $\operatorname{dog}$ have their origin in the vagus and the sympathetic nerves, as is the case with man and other mammals. The vagus-originating nerves consist of fine unmedullated vegetative fibres of parasympathetic nature and a small number of thick medullated sensory fibres, and the sympathetic and parasympathetic fibres come into intricate ramification and anastomosis before they reach the alimen- 
tary tract and thereafter upon penetrating the outer layer of the tunica muscularis of the wall of the oesophagus and the stomach, so that the histological distinction between the two has vanished here, but as the sensory fibres consist of stout medullated fibres, these are clearly distinguishable from the minute vegetative fibres.

The incoming nerve fibres, similar to those in human and other mammalian digestive ducts, pass over into the AUERBACH's plexus in the tunica muscularis, between its outer and inner layers. A part of them end here in close contact with the nerve cells in the plexus, but the others penetrate further through the inner muscle layer, together with the long processes sent out by the nerve cells, into the MEISSNER's plexus formed in the submucosa.

There are some nerve cells in the MEISSNER's plexus, but their number is very small and they stand far lower in development than those in the AUERBACH's plexus, as detailed below. By the way, I wish to point out that nerve cells are of ten found in the upper surface of the submucosa, not rarely in the muscularis mucosae as well and even sometimese in the propria mucosae, as is the case with the small intestine. The nerve fibres from the MEISSNER's plexus spread out through the muscularis mucosae into the propria, to form proprial plexus of minute meshes built of very fine fibre bundles.

The termination of the vegetative fibres is represented by the STÖHR's terminalreticulum, as was the case with the stomach of man (STÖHR, SATO), white mice (OHI) and hedgehogs (TOYOTA). Typical formation of the terminalreticulum is observable in the tunica muscularis (Fig. 1) and the muscularis mucosae. In the propria also the very distinctly developed terminalreticulum is observed spreading to the surroundings of the gastric glands in the cardiac part of the stomach.

As shown in Fig. 1, the terminalreticulum consists of a net-like cord formed by extremely fine nerve fibrils, never ending free but always mutually anastomosing to form a wide-spread net-like system controlling all related tissue cells by contact. Here and there in the terminalreticulum are seen SCHWANN's nuclei. Terminalreticulum is also found surrounding many nerve cells in common, especially in the AUERBACH's plexus (Fig. 2), composed of net-like arrangement of rather thicker fibrils and containing no SHWANN's nuclei, similar to the findings by TOYOTA in the stomach of hedgehogs. The transmission of stimuli from the terminalreticulum to the nerve cells is seemingly initiated by an excitation of the mantle cells around the nerve cells, as has been assumed by SETO and his disciples, and therce secondarily to the nerve cells and their short processes by way of chemical substances secreted by the mantle cells. 


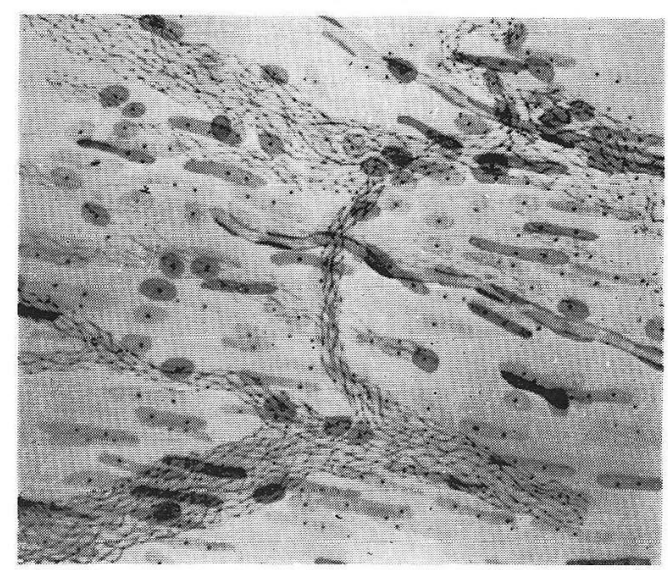

Fig. 1. Distinctly developed terminalreticulum (STOHR) distributed in the inner layer of the inferior part of a canine oesophagus. SETO's silver impregnation. $\times 500$, reduced to $1 / 2$.

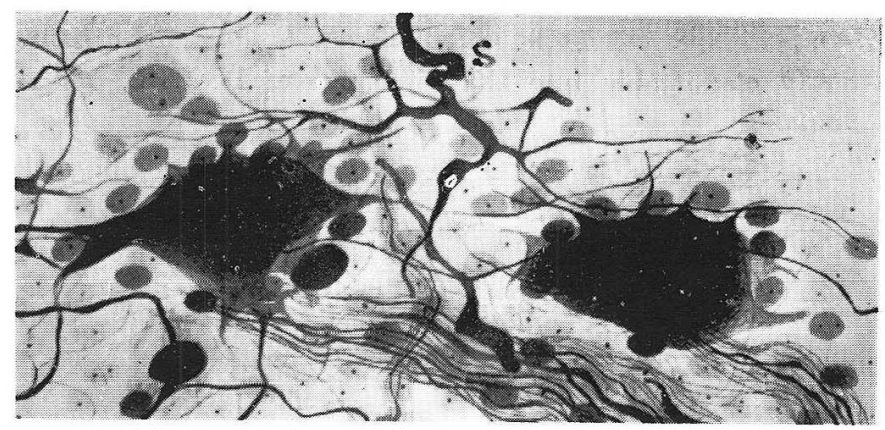

Fig. 2. Two DOGIEL's type I cells and a complex branched sensory termination $\mathbf{s}$ in the AUERBACH's plexus of the inferior part of

a canine oesophagus. Same staining. $\times 700$, reduced to $1 / 2$.

The nerve cells seen in the inferior part of the oesophagus and the cardiac part of the stomach of a dog are generally multipolar, as shown in Figs. 2 and 3, which can be classified into DOGIEL's cell types I and II by the conformation of their short processes and their terminations. Now, according to STÖHR, REISER, YOSHITOSHI, KUMAGAWA and SATO, the nerve cells in human gastric and intestinal walls belong in their large majority to type I cells, those belonging to type II cells being found only rarely. GREVING and LAWRENTJEW reported similar observations also in mammalian alimentary tracts. In white mice, according to OHI, the short processes of the nerve cells in the gastric wall are so low in development that it is impossible to mark the classi- 


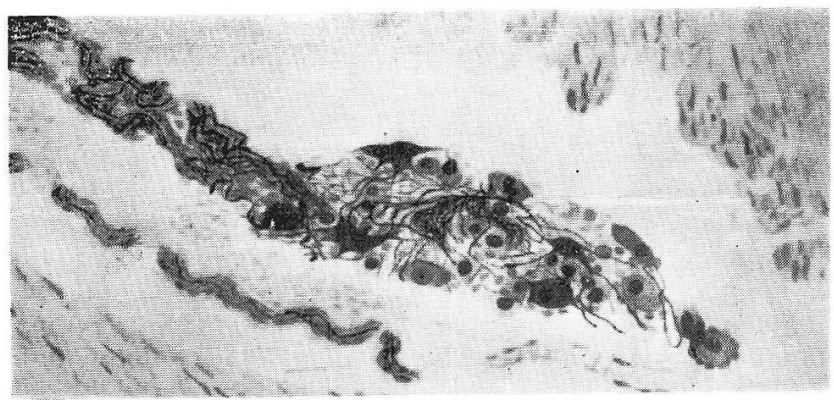

Fig. 3. Many DOGIEL's type II cells found in a ganglion of AUERBACH's plexus in the inferior part of a canine oesophagus. A nerve bundle seen in the left is composed of thin vegetative and thick sensory nerve fibres. Same staining. $\times 160$, reduced to $1 / 2$.

fication of the nerve cells, but TOYOTA says that the nerve cells in the AUERBACH's plexus in the stomach of hedgehog chiefly belong to DOGILL's type I cells and partly to type II cells, though in development they stand far below those in man.

In my canine specimens, the nerve cells in the AUERBACH's plexus are distinctly classifiable into the two types of DOGLEL, the cells of both types being observed in a similar frequency, that is, the cells type II are not at all a rarity. However, as there are also a rather large number of infantile cells with as yet unspecialized types of nerve processes, the cells in the canine AUERBACH's plexus may be called far inferior in development than those in human specimens.

The nerve cells in the MEISSNER's plexus in the stomach are very poor, both in their number and in their development, and all are represented as infantile cells so that the classification into the two DOGIEL's types is quite impossible here. This result is in agreement with TOYOTA's and Olll's observations on the stomachs of hedgehogs and white mice. Some researchers reported failure of detecting nerve cells in MEISSNER'S plexus in mammalian oesophagi, but I could observe their conspicuous existence in my canine oesophagus, in agreement with the observations of de WITT, SABUSSOW and LAWRENTJEW. However, it goes without saying that those cells were also of infantile development.

In short, the vegetative innervation of the inferior part of oesophagus and especially of the cardiac part of the stomach of dog is not much different in essence from that in man, white mice and hedgehogs, but in development, it stands far below that of man, though somewhat higher than in white mice and hedgehogs, especially in the development of nerve cells. 
There has been no report on discovery of sensory nerve terminations in the walls of mammalian alimentary tracts to date, except by HARTING, who described some so-called Schlingenterritoria in the submucosa and the propria mucosae of the lower oesophagus of rabbits. On the other hand, SADA has established the rather numerous and variegated existence of sensory terminations in human oesophagus. I have succeeded in discovering thick medullated sensory fibres running in the inferior part of canine oesophagus and clarifying their terminal formation. I will detail hereunder my observations on my canine oesophagus samples in collation with the reported sensory terminations found in the human oesophagus.

'In the connective tissue between the muscle bundles in the muscularis in the canine oesophagus, no sensory termination seems to be formed, contrary to the reported observation in human oesophagus. However, as in the case such terminations are preferentially found in the medial part of the oesophagus, it may be that, in dogs too, such terminations are found in the upper part of the oesophagus. SADA also mentions the second type of terminations, namely, special complex branched terminations strongly developed in the AUERBACH's and MEISSNER's plexus, especially in the groups of nerve cells therein. In my canine specimens, I also found some sensory terminations very much resembling those described by SADA in the ganglia of the AUERBACH's plexus in the inferior oesophagus.

These intragangliar sensory terminations presumably originate in the sensory fibres from the vagus nerve, as is the case with human oesophagus. The thick sensory fibres running into the ganglia, after losing their myelin, run winding courses showing peculiar change in

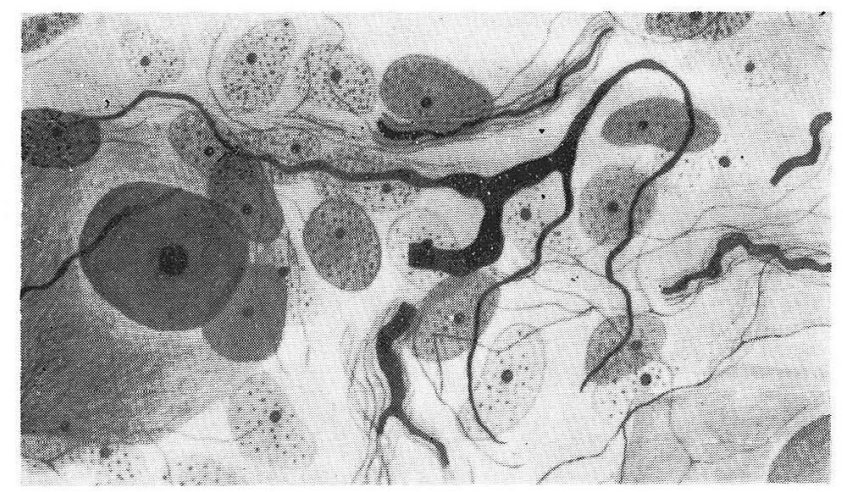

Fig. 4. A branched sensory termination found in a ganglion of AUERBACH's plexus. Inferior part of a dog oesophagus. Same staining. $\times 1500$, reduced to $2 / 3$. 
size, sending out in the course numerous branches, which also run peculiar winding courses to end in sharp points (Figs. 2 and 4). These intragangliar sensory terminations are, however, much simpler in formation in dogs than in man, such reticular or glomerular complex branched terminations frequently found in man being scarcely observable in dogs. In the MEISSNER's plexus of the canine ocsophagus, no such intragangliar termination was ever found, though some were reported in human oesophagus.

In the next place, we may mention the terminations resembling the so-called Schlingenendapparate running out in serpentine course and found by SADA in the human vesophagus. These are chiefly formed in the muscularis mucosae and in the propria mucosae. In human specimens, the fibres send out frequent side branches in their peculiary serpentine courses, but by dog, such ramification is rarely, if ever observed. Typical serpentine terminations are found in the propria mucosae of the cardiac part of the canine stomach.

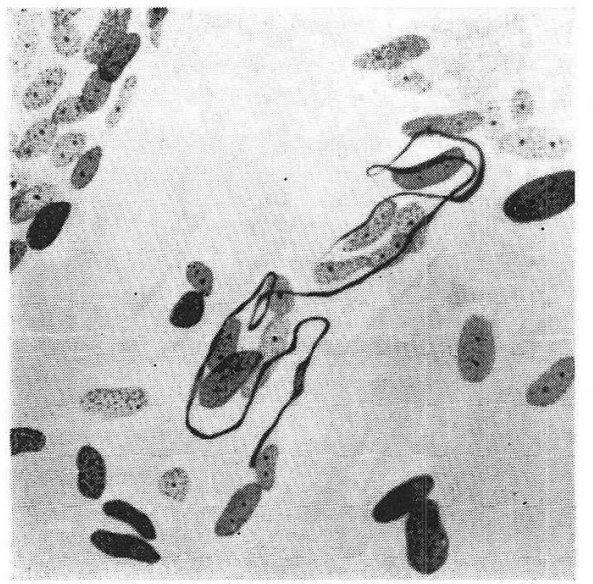

Fig. 5. A serpentine sensory termination seen in the propria mucosae in the inferior part of a canine oesophagus. Same staining. $\times 1000$, reduced to $1 / 2$.
Fig. 5 shows a termination belonging to the serpentine type found in the propria of the inferior oesophagus. The sensory fibre here runs in a winding course showing a rather remarkable change in size, but its serpentine course is nothing to speak of, no side branches are sent out and the end is sharp. Some special cell nuclei are seen along the fibre here and there. Fig. 6 is also a similar termination in the propria of the same part, with change in size, and ending sharply without branching.

In the third place, there are unbranched and simple branched terminations also formed generally in the propria of the canine oesophagus. In the former, a sensory fibre, after losing its myelin, running a rather long course without showing an appreciable winding, chiefly comes to a sharp end, while in the latter, it branches out into two or three rami which generally end in sharp points. Fig. 7 shows such a branched termination, in which a nerve fibre, after losing its myelin, runs a course of little winding 
and branches out into three terminal branches which all end sharply. Special cell nuclei are seen accompanying these terminations too.

Thus, we may find sensory terminations in the inferior part of the oesophagus of a $\operatorname{dog}$ as in man, but their number can never be called large, and it took considerable exertions to ascertain their existence. SADA has found some rather simple-formed glomerular terminations in the human oesophagus, but

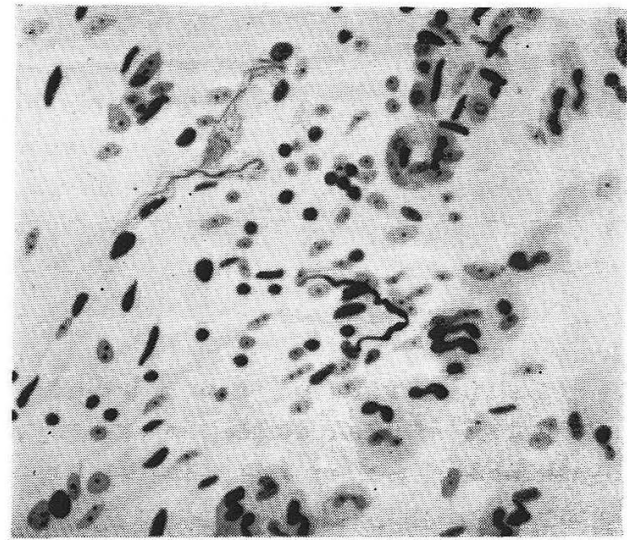

Fig. 6. A serpentine sensory termination showing a change in size and ending sharply in the propria mucosae close to the muscularis mucosae. Inferior part of a canine oesophagus. Same staining. $\times 500$, reduced to $2 / 3$. I could detect none of such complex typed terminations in my dog oesophagus, my painstaking search notwithstanding.

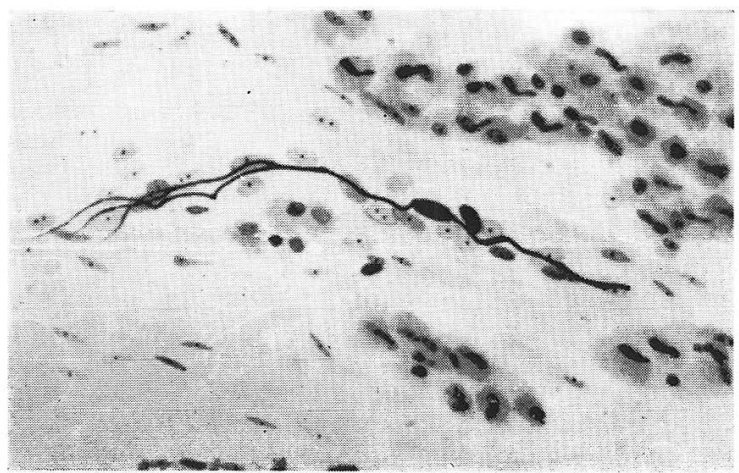

Fig. 7. A simple branched sensory termination found in the propria mucosae of a canine oesophagus. $\times 480$, reduced to $1 / 2$.

As was the case with man (SATO), white mice (OIII) and hedgehogs (TOYOTA), sensory fibres presumably originating in the vagus nerve and their terminations were found existing in the cardiac part of the stomach of dogs, but their number was also very small so that the effort required for their detection was rather heavy. These sensory fibres being naturally thick in size, their distinction from the thin vegetative fibres was an easy matter. 
In the canine stomach, the sensory terminations in the cardiac part are not formed in the tunica muscularis, as by man, but rather in the submucosa and the propria mucosae. Especially, the majority were found in formation in the propria, the sensory fibres frequently intruding into the connective tissue between the gastric glands. It is of interest that these findings are similar to those obtained in connection with the stomach of a hedgehog (TOYOTA).

The number of sensory terminations in the cardiac part of a canine stomach is seemingly somewhat larger than that in man and smaller than that in a white mouse or a hedgehog, a difference perhaps owing to the size of their respective stomachs, because the density in the distribution of sensory fibres in the large-areaed human stomach must be much smaller than by the minor mammals, since the total number of the sensory fibres supplying the stomach must be approximately equal in all cases.

The sensory terminations in the cardiac part of the canine stomach are chiefly represented by the simplest type of terminations, that is, the unbranched terminations, more complexly specialized terminations, such as branched and glomerular terminations, being of rarest occurrence. However, the unbranched terminations here belong to the serpentine type with their peculiar sinuous running courses, in most cases, and a type nearly resembling it.

Fig. 8 shows a typical serpentine termination without marked change

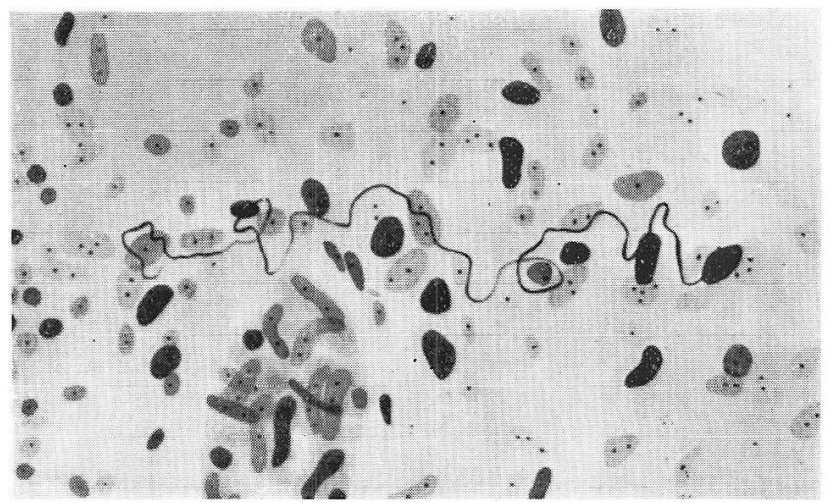

Fig. 8. A typical serpentine sensory termination found in the propria mucosae of a cardiac part of a canine stomach. Same staining. $\times 700$, reduced to $1 / 2$.

in size, found in the propria of the cardiac part of a canine stomach. which shows no tendency of ramification, being similar to those in the canine inferior oesophagus in this respect, and also in that the fibre 
ends in a sharp point. Figs. 9 and 10 illustrate quasi-serpentine terminations, also found in the propria of the same part, in which the thick fibres show considerable change in size but no typical sinuolis winding in their courses, and end sharply after an irregular meandering.

It is noteworthy that the sensory terminations in the cardiac part of the canine stomach are much simpler in construction, though somewhat larger in number, than in human stomach. In any case, however, the fact that sensory fibres of cerebrospinal origin do come into and form their terminations in the inferior oesophagus and the cardiac part

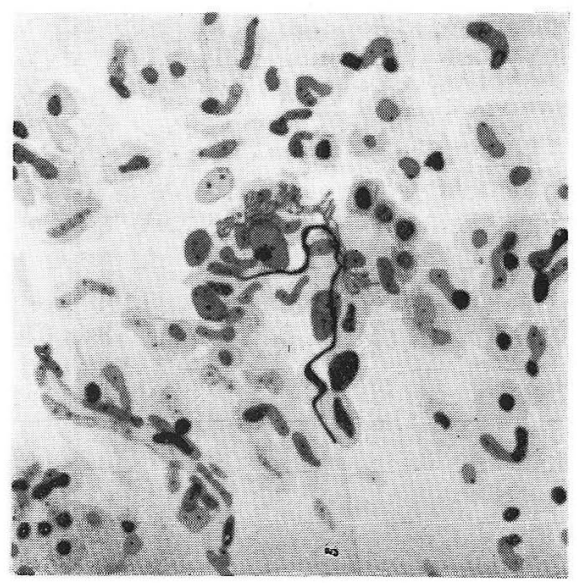

Fig. 10. A same termination found in the muscularis mucosae of the cardiac part of a canine stomach. Same staining. $\times 700$, reduced to $2 / 3$.

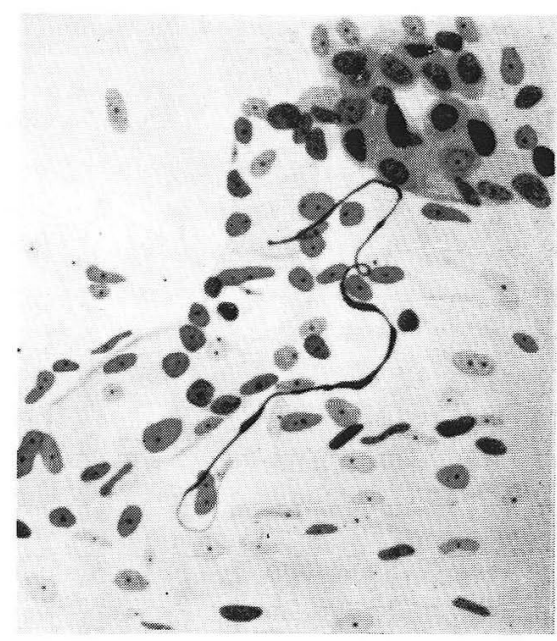

Fig. 9. A serpentine sensory termination showing a change in size and ending sharply found in the propria mucosae of the cardiac part a canine stomach. Same staining. $\times 500$.

of the stomach even in a dog must be looked upon as suggestive of the reception of sensory stimuli by medullated sensory fibres, and not by vegetative nerve fibres, as accepted in the past. The recent and many-sided works in this laboratory, of course, have contributed much in elucidating the problem.

\section{Summary.}

The vegetative innervation of the inferior part of the oesophagus and the cardiac part of the stomach of a dog is nothing different from that in human (STÖHR, SATO), a white mouse (OHI) and a hedgehog (TOYOTA) alimentary tract in essence, but in development, it stands below that of man but above that of a white mouse or a hedgehog, especially 
in the high evolution of the nerve cells. In a dog, the nerve cells in the AUERBACH's plexus are indeed somewhat inferior in development than those in man, but DOGIEL's types I and II cells are present in distinguishable maturity and in a similar frequency, beside some unspecialized infantile type cells. The nerve cells in the MEISSNER's plexus are very poorly developed, representing only infantile type cells. It is noteworthy that infantile nerve cells are not rarely also found in the muscularis mucosae and the propria mucosae of the cardiac part of the canine stomach.

The vegetative nerve fibres terminate in these parts, as well in other parts of the body, in STÖHR's terminalreticulum, which stands in tactile control over all tissue cells coming in contact.

In the inferior part of the oesophagus of a dog have been found some sensory fibres and their terminations, although, may be, in a small quantity. The first type of the sensory terminations in the inferior oesophagus is that of very irregularly arranged branched terminations found in the AUERBACH's plexus, much inferior in development than those in man (SADA). The second represents the serpentine and similar terminations. These terminations do not ramify, as is usual in man, but always end unbranched in the muscularis mucosae and the propria mucosae. The third consists of unbranched and simple branched terminations of fibres chiefly formed in the propria which do not show any winding worth mentioning in their courses. No complex-typed glomerular terminations as found in the propria of the human oesophagus could be detected here in the canine oesophagus.

There are also a small number of sensory fibres and their terminations found in the cardiac part of the canine stomach. They are rarely formed in the tunica muscularis, as is usual in man, but in most cases in the submucosa and the propria mucosae, and especially in a large number in the latter, an observation strongly reminding of the stomach of hedgehogs (TOYOTA).

These terminations generally belong to the unbranched or simplest terminations, such complex terminations of glomerular and branched types as found in human stomachs being scarcely observable. These terminations are of the serpentine type ending in peculiar sinuous courses and of similar conformation, but not send out lateral branches, as in man, and the fibres end in sharp points in most cases.

The above stated fact that there are found some sensory nerve terminations in unmistakable existence in the inferior part of the oesophagus and the cardiac part of a dog, in corraboration of the results of many works in this field carried out at this laboratory, endorses the theory that the reception of sensory stimuli in these parts does not 
rely upon vegetative fibres, but is effected by cerebrospinal sensory fibres in all cases.

\section{内容自抄，}

犬食道下部及び噴門部に於ける植物神経の分布状態は人間（Stöhr, 吉利, 佐藤), 白鼠 (大井) 及び針鼠（豊田）に於けると本質的差異を示さない が，其発達状態は人間に於けるより劣勢，針鼠及び白鼠飞於けるよりは稍 々優勢。特飞神経細胞の発達状態飞於て然りである. 即ち Auerbach 氏神 経丵内の神経細胞は人間に於けるよりは発達劣勢の, 然し略ぼ同数に存す るDogiel 氏第 1 型及び第 2 型細胞と所属不明の幼若型細胞とから成る. Meissner 氏神経叢内の神経細胞は其発達甚だ劣勢で，何れも幼若型として 表わされるに過ぎない，尚招噴門部では神経細胞が稀ならず粘膜筋膜並び に固有膜内にも発見される事は注目に価する。

植物神経線維の終末は之等の部に於ても Stöhr の終網と依り表わされ， 終網は総ゆる被主莘細胞飞対して專ら接触的主宰関係を示す。

犬食道下部亚びそ噴門部に於ても少量ではあるが，知覚線維並びそ其終 末の存在が確認された。食道下部に於ける知覚終末は, 第1飞 Auerbach 氏神経叢内に形成される甚だ不規則な配列を示す分岐性終末で表わされる. 之は人間に見られるもの（定）よりは遙かに小規模のものである.

第 2 は蛇行状終末或は之飞類似の終末である。等は人間に見られるも のと多少異り, 側枝を出す事なく, 殆んぞ総て非分岐性であり, 専ら粘膜 筇膜から固有膜にかけて発見される. 第 3 の知覚終末も専ら固有膜内に形 成されるもので，特記すべき迁曲走行を示さない非分岐性終末並びと単純 な分岐性終末に依って表わされる。尚招犬食道下部に於ては人間食道固有 膜内に見られる糸求状終末の如き複雑性終末の存在は認められなかった。

犬噴門部に於ても少量ではあるが知覚線維並びそ其終末の存在を見る. 此知覚終末は人間の埸合と異って筋層内には殆えど形成されず, 專ら粘膜 下膜から粘膜固有膜にかけて形成され，特に其大多数は固有膜内に発見さ れる。此状態は針鼠胃飞於ける所見（豊田）に甚だ類似する。

知覚終末は專ら非分岐性終末即ち最単純性終末として表わされ，人間に 見られる様な分岐性及び糸求状終末の如き複雑性終末は殆んど認められな い. 尚招之等非分岐性終末の多くのものは特有な波状走行を示す所謂蛇行 状終末或は之飞類似の終末に所属するが，人間食道のるのと異って側枝を 出す事なく，其先端は概ね尖鋭状飞終る.

以上犬の食道下部及び噴門部内にも著明な知覚神経終末の存在する事は 
本問題に関する当教室の他の業績と相俟って此部に於ける知覚感受も亦植 物線維飞依る事なく，常に脳资髄性知覚線維に依るものであることを愈々 明かにするものである。

\section{References.}

Greving: Z. Anat. 61 (1921). S. 1. - Harting: Z. mikr.-anat. Forsch. 35 (1934). S. 631. - Kumagawa: J. orient, Med. (Jap.). 34 (1941). P. 717. Lawrentjew : Anat. Anz. 64 (1927). S. 59. - Z. mikr.-anat. Forsch. 16 (1932). S. 123. - Ohi: Tohoku J. exp. Med. 60 (1954). P. 67 a. 289. Reiser: Z. Zellforsch. 15 (1932). S. 761. - Sabussow : Anat. Anz. 44 (1913). S. 61. - Sada: Psych. et Neurol. jap. 46 (1942) P. 175. - Sato: Tohoku Igaku Zassi. (Jap.) 40 (1949). P. 1. - Seto: Advance of Medicine. (Jap.) Vol. 5. Nanjo Shoten, Tokyo, 1948. P. 225. - Tohoku J. exp. Med. 54 (1950). P. 85. - Stöhr: Z. Zellforsch. 16 (1932). S. 123. - 27 (1937). S. 341 . 29 (1939). S. 569. - Toyota: Arch. hist. jap. 7 (1955). P. 573. - Utsushi : Tohoku J. exp. Med. 60 (1954). P. 311. - de Witt: J. comp. Neur. 10 (1900). P. 382. - Yoshitoshi: J. orient. Med. (Jap.) 34 (1941). P. 717. 